Review

\title{
Exosomes and Their Role in the Life Cycle and Pathogenesis of RNA Viruses
}

\author{
Harendra Singh Chahar $^{1}$, Xiaoyong Bao ${ }^{1,2}$ and Antonella Casola ${ }^{1,2, *}$ \\ ${ }^{1}$ Departments of Pediatrics, University of Texas Medical Branch at Galveston, Galveston, TX 77555, \\ USA; E-Mails: hachahar@utmb.edu (H.S.C.); xibao@utmb.edu (X.B.) \\ ${ }^{2}$ Sealy Center for Vaccine Development, University of Texas Medical Branch at Galveston, Galveston, \\ TX 77555, USA \\ * Author to whom correspondence should be addressed; E-Mail: ancasola@utmb.edu; \\ Tel.: +1-409-747-0581; Fax: +1-409-772-1761.
}

Academic Editor: Yorgo Modis

Received: 15 April 2015 / Accepted: 5 June 2015 / Published: 19 June 2015

\begin{abstract}
Exosomes are membrane-enclosed vesicles actively released into the extracellular space, whose content reflect the physiological/pathological state of the cells they originate from. These vesicles participate in cell-to-cell communication and transfer of biologically active proteins, lipids, and RNAs. Their role in viral infections is just beginning to be appreciated. RNA viruses are an important class of pathogens and affect millions of people worldwide. Recent studies on Human Immunodeficiency Virus (HIV), Hepatitis C Virus (HCV), human T-cell lymphotropic virus (HTLV), and Dengue Virus (DENV) have demonstrated that exosomes released from infected cells harbor and deliver many regulatory factors including viral RNA and proteins, viral and cellular miRNA, and other host functional genetic elements to neighboring cells, helping to establish productive infections and modulating cellular responses. Exosomes can either spread or limit an infection depending on the type of pathogen and target cells, and can be exploited as candidates for development of antiviral or vaccine treatments. This review summarizes recent progress made in understanding the role of exosomes in RNA virus infections with an emphasis on their potential contribution to pathogenesis.
\end{abstract}

Keywords: exosomes; microvesicles; RNA virus; pathogenesis; miRNA; infection 


\section{Introduction}

Exosomes are lipid bilayer membrane-enclosed nano-sized (30-100 nm) vesicles with a density of $1.13-1.19 \mathrm{~g} / \mathrm{mL}$, secreted by virtually all cell types, and formed during the maturation of endosomes upon invagination and budding of the limiting membrane of late endosomes as intraluminal vesicles (ILVs) of multivesicular bodies (MVBs). Exosomes were first observed in the early 1980s in the culture media of reticulocytes [1-3]. In their study, Harding et al. (1983) reported that clathrin-coated, pit-mediated endocytosis led to enrichment of gold-labeled transferrin on vesicles inside non-lysosomal multivesicular endosomes [1]. They observed that these endosomes, commonly known as MVBs, fused with the plasma membrane and released their inner vesicles by exocytosis. Johnstone, in 1987, coined the term "exosomes" for such vesicles, which are released from cells by exocytosis [1]. Exosomes are released by almost all cell types and have also been confirmed in all bodily fluids such as blood, urine, saliva, breast milk, bronchial lavage, cerebral spinal fluid, and amniotic fluid [4-19]. In order to best adapt to the surrounding microcosm and execute their functions and duties, continuous communication, achieved through methods like direct cell-cell contact or transfer of secreted molecules, is essential for cells and tissues. Although initially it was proposed that secretion of exosomes was a mechanism of discarding cellular waste [16,20,21], in recent years exosomes have emerged as an important tool for intercellular communication through the transfer of biologically active proteins, lipids, and RNAs [22]. Exosomes have been implicated in normal as well as pathophysiological conditions, such as lactation, immune response, neuronal function, development and progression of liver disease, neurodegenerative diseases, cancer, and viral infections [16,22-27]. Exosome-mediated extracellular delivery of nucleic acids and proteins among virally infected and uninfected bystander cells have been shown to play an important role in viral pathogenesis and control of host immune responses to infection [28-31]. This certainly suggests a crucial role for exosomes in the viral life cycle and this review focuses on the important role exosomes play in the life cycle of RNA viruses with an emphasis on their potential contributions to pathogenesis.

\section{Molecular Composition of Exosomes}

Exosomes are essentially cytoplasm enclosed in a lipid bilayer with exposed external domains of transmembrane proteins. Exosomes may contain all types of biomolecules like proteins, carbohydrates, lipids, and also a nucleic acid signature of source of origin. New purification methods providing highly pure preparations of exosomes have allowed the use of proteomic and molecular techniques to understand the molecular composition of exosomes. The presence of cellular proteins in exosome preparations from various cellular sources has been analyzed by various methods like western blot, fluorescence-activated cell sorting (FACS), ELISA, and mass spectrometry [11,32-39]. Extensive analyses involving quantitative RT-PCR and RNA deep sequencing to identify RNA species that are present in exosomes have also been carried out [40-46]. These extensive and in-depth analyses revealed that a defined subset of cellular proteins, probably involved in exosome biogenesis and maybe in some common exosome functions, is targeted specifically to exosomes. This may include cytoskeletal components such as actin and actin-binding proteins, tubulin, and proteins involved in intracellular membrane fusions and transport such as Annexins and Rab (Ras (rat sarcoma) genes from the rat 
brain) proteins $[47,48]$. Molecules involved in signal transduction such as protein kinases (14-3-3) and heterotrimeric G proteins, heat shock proteins (HSPs), such as HSP70 and HSP90, and MHC class I and II molecules are also part of this defined but common set of exosome proteins. Tetraspanins including CD9, CD63, CD81, and CD82, as well as cytoskeletal components such as actin, are among the most abundant proteins in exosomes from virtually any cell type. Since exosomes are generated through invagination of late endosomes, a variety of host proteins that participate in vesicle formation and trafficking such as apoptosis linked gene (ALG), 2 interacting protein X (ALIX), and tumor susceptibility gene 101 (TSG101) are also incorporated into the exosomes [49]. All of these proteins have been considered as consensus markers for exosomes [50-52].

Exosomal lipid composition has also been characterized and exosomes are rich in sphingomyelin, gangliosides, phosphatidylserine, and cholesterol [53]. Nucleic acid signature is the other important component of exosomes and recent studies have focused on exosomal nucleic acid content. It has been demonstrated that exosomes carry biologically active mRNA, miRNA, other non-coding RNA, and a limited amount of DNA coding for ribosomal RNA [54-58]. However, the RNA and protein composition of exosomes varies in both quantity and type of molecules, depending on the origin and physiological/pathological state of the cells, suggesting that recruitment of RNA and protein into exosomes is a regulated process [55,59]. The exosome structure is graphically represented in Figure 1.

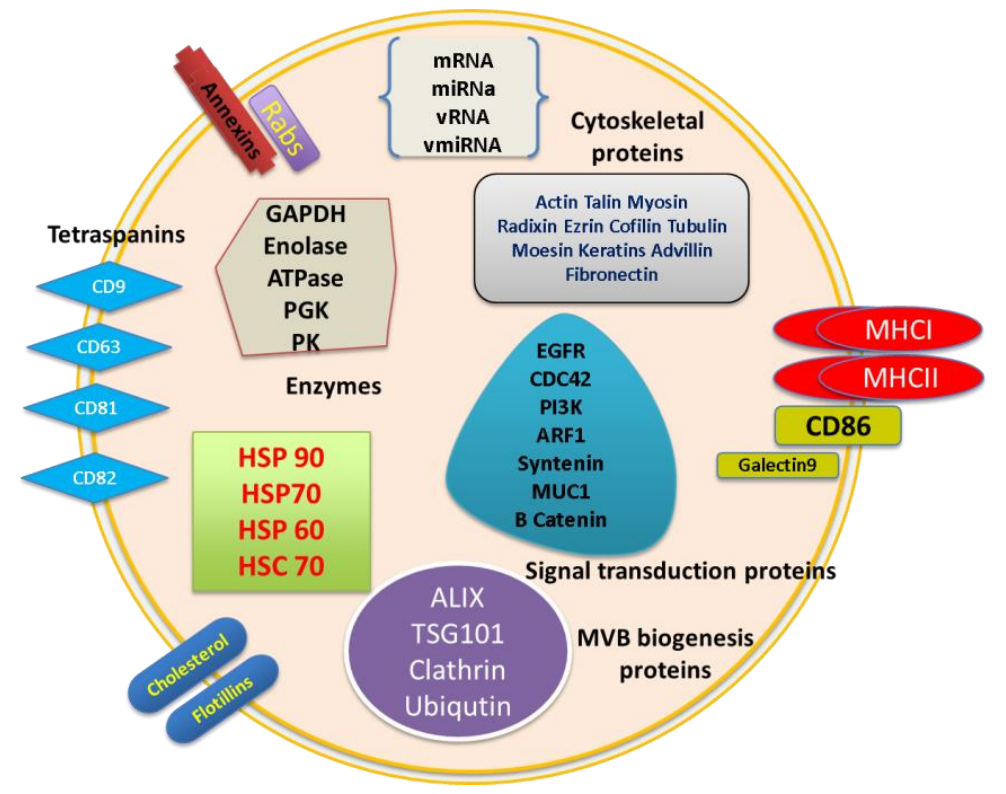

Figure 1. Structure and composition of exosomes. Exosomes contain a plasma membrane-derived phospholipid bilayer membrane. The composition depends on the cell type of origin, state of health of the host, and extracellular stimuli. Exosome contents include mRNA, miRNA, DNA, and proteins like annexins, tetraspanins, Alix, TSG101, MHC molecules, Rab proteins, cytoskeletal proteins, enzymes, and signal transduction proteins. GAPDH: Glyceraldehyde 3-phosphate dehydrogenase PGK: 3-phosphoglycerate kinase, PK: pyruvate kinase, EGFR: epidermal growth factor receptor, CDC42: cell division control protein 42, PI3k: phosphatidylinositide 3-kinases, ARF1: ADP-ribosylation factor 1, MUC1: Mucin 1, vRNA: viral RNA, vmiRNA: viral miRNA. 


\subsection{Biogenesis of Exosomes}

Exosome biogenesis starts with the endocytosis and formation of early endosomes. The early endosome develops into the late endosome upon maturation, which is characterized by the formation of intraluminal vesicles (ILV) inside the lumen of the endosome. The ILVs, 30-100 nm in diameter, are formed by inward budding of the endosomal membrane, randomly engulfing portions of the cytosol and incorporating transmembrane and peripheral proteins into the invaginating membrane; this leads to formation of multivesicular bodies (MVBs) [5,60,61]. Although endocytosis and trafficking of plasma membrane receptors into MVBs is responsible for their degradation upon fusion with lysosomes [62], the fate of the MVBs may vary and not all MVBs are degraded in lysosomes, with a subset fusing with plasma membrane and resulting in generation of exosomes. The process of exosome biogenesis and cargo sorting is still not well understood and many studies suggest that the mechanisms of exosome biogenesis can be cell specific [63]. Exosomes are mainly secreted by two different mechanisms, constitutive release via the Trans-Golgi network and inducible release [64,65].

In the vesicle generation process, the endosomal sorting complexes required for transport 0 (ESCRT0) ubiquitinate proteins for MVB delivery and also recruit ESCRTI to endosomal membrane, which in turn recruits ESCRTII and ESCRTIII [66,67]. ESCRTIII mediates formation of polymeric filaments, which leads to membrane invaginations and eventually results in ILV formation [68]. The presence of ESCRT components in exosomes was identified using high throughput protein analysis methods, and downregulation of key components of ESCRT system abrogates ILV formation and release of exosomes [69]. Various studies also suggest ESCRT-independent mechanisms of exosome biogenesis and release. For example, in oligodendroglial cells exosome generation is regulated by the production of a lipid ceramide [70]. Recently, a CD63 tetraspanin-mediated mechanism of cargo sorting and ILV formation was reported, which is independent of ESCRT and ceramide [71]. Once the MVBs are formed, the soluble N-ethylmaleimide sensitive factor attachment receptor (SNARE) proteins and GTPases mediate their fusion with plasma membrane. Rab 35 has been recently shown to be part of the MVB docking to the membrane and depletion of Rab35 significantly decreased exosome release [72]. Although exosomes and ILVs are similar and generated through common mechanisms, cells have different populations of vesicles $[47,73,74]$ and the mechanisms that contribute to exosome formation and cargo sorting within these vesicles is still not well understood. The process of exosome biogenesis is summarized in Figure 2. 


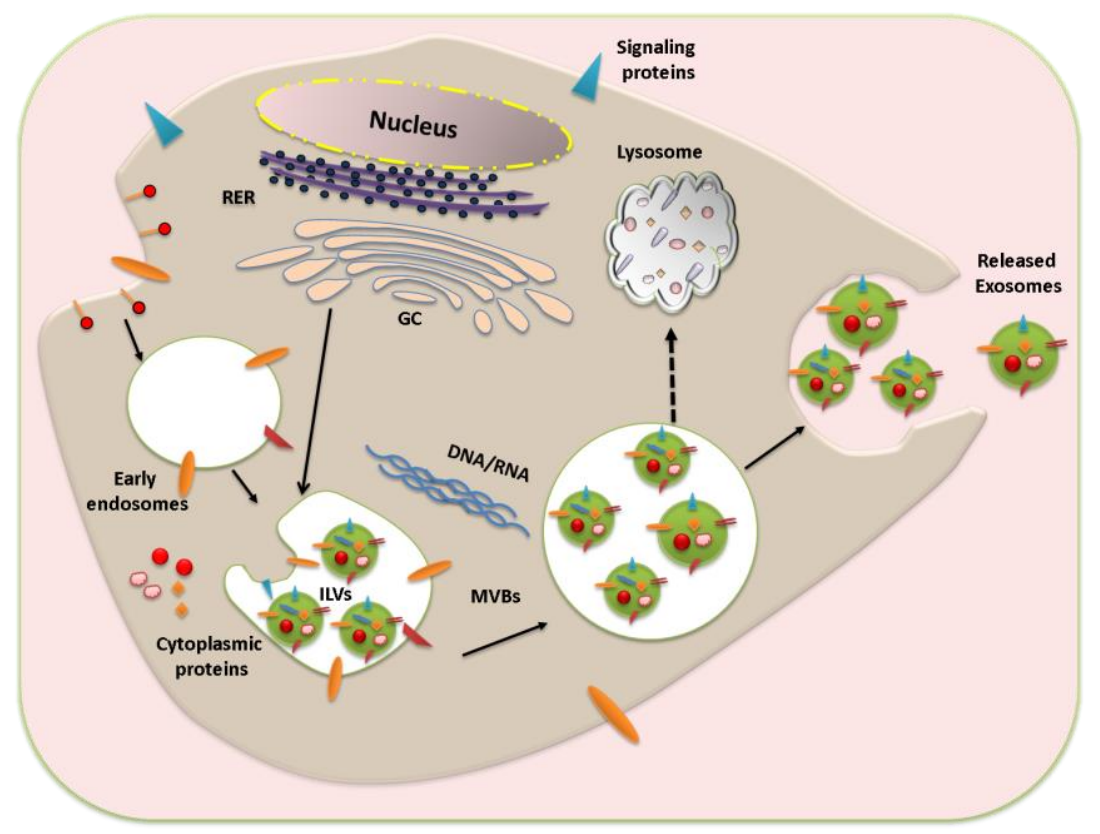

Figure 2. Schematic representation of exosome biogenesis and release. Exosome generation starts with early endosome formation during endocytosis. The membrane proteins are internalized through clathrin-coated vesicles and delivered to early endosomes. This leads to intraluminal vesicles (ILVs) formation by inward budding of the limiting membrane and multi vesicular bodies (MVBs) are formed. Upon maturation the exosome-filled MVBs are either sent to lysosomes for degradation or fused with the plasma membrane to release exosomes to the extracellular milieu. RER: Rough Endoplasmic Reticulum, GC: Golgi complex.

\subsection{Exosome Characterization}

Various viruses like paramyxoviruses, $\mathrm{HBV}, \mathrm{HCV}$, rhabdoviruses, herpersviruses, filoviruses, and arenaviruses utilize or need the ESCRT pathway for their release [75-77]. Characterization and investigation of exosomes derived from virus-infected cells is a tough task as these vesicles often are of similar density and fall in the same size range as many of these viruses, making it necessary and at the same time challenging to separate the two populations. Conventionally, the exosomes are isolated from culture media or bodily fluids using a sequential sucrose-gradient ultracentrifugation procedure [78]. Other methods of exosome isolation/purification include microfiltration technologies, microfluidic devices [79-82], exosome precipitation reagents like ExoQuick ${ }^{\mathrm{TM}}$ (System Biosciences, Mountain View, CA, USA), and Total Exosome Isolation reagent (Life Technologies Grand Island, NY, USA), as well as antibody-coated magnetic bead-based immunopurification [38,83]. Similar sequential centrifugation and ultracentrifugation methods are used to purify many enveloped or non-enveloped viruses [84-87]. For instance, exosomes derived from HIV or HCV-infected cells cannot be readily distinguished or separated from infectious viral particles by conventional biophysical techniques as they share similar buoyant densities and sedimentation velocities [22,88-90]. Hence, when isolating exosomes from virus-infected cells, it becomes critically important to make sure that the pelleted material is exosomes and not virus particles. To address this, various exosome characterization methods have 
been developed including measurement and analysis of size distribution using NanoSight nanoparticle tracking analysis system, visualization of exosomes using electron microscopy, and immunoblot analysis of universal exosome protein markers like CD63, CD81, TSG101, Annexin5, ICAM1, FLOT1, and Alix (Figure 3).

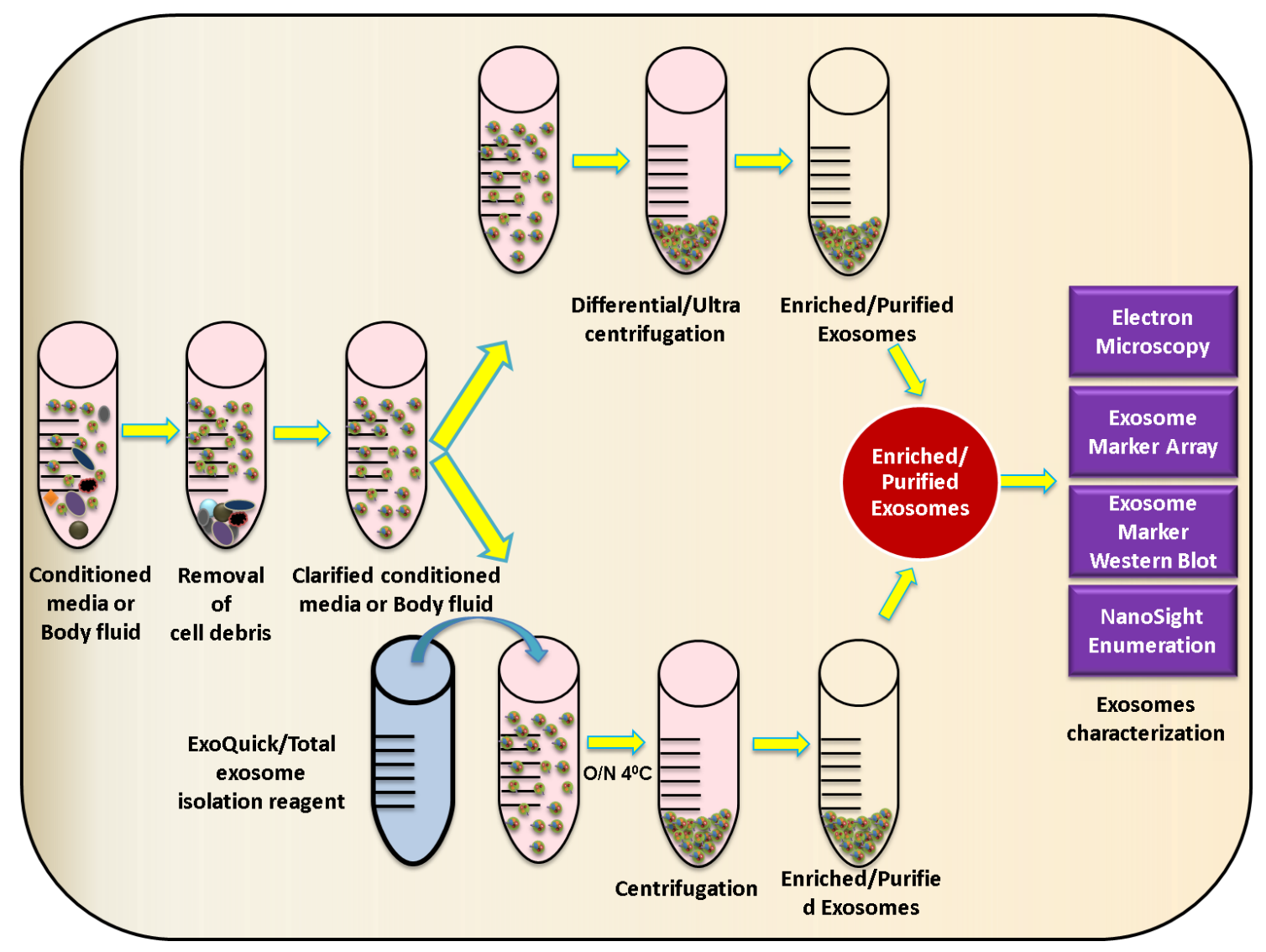

Figure 3. Schematic representation of exosome isolation strategies. Graphical representation of exosome isolation by both ultracentrifugation- and precipitation reagent-based isolation procedures, and analytical tools for exosome identification.

When using immunoblot analysis, the exosome marker chosen for characterization should be selected with caution, as some viruses have been shown to incorporate exosome proteins. For example, proteomic studies utilizing liquid chromatography and tandem mass spectrometry (LC-MS/MS) found that influenza virus incorporates exosome markers ICAM1, Annexin A3, CD81, and CD9, while CD63 and ALIX were not present [91]. Similarly, exosomes and retroviruses share a variety of molecules like MHC-II [92,93], integrins (CD11a, CD18), co-stimulatory molecules (CD28, CD54), and complement neutralizing molecules (CD55, CD59) [5,35,94,95]. Various other host molecules/proteins acquired by enveloped viruses are reviewed in Cantin et al. [95]. Hence, the enriched exosomes isolated by ultracentrifugation or precipitation reagent should be further subjected to immunopurification methods like CD63 immunomagnetic bead isolation or other efficient virus purification strategies to obtain contamination-free populations of exosomes (Figure 4). 


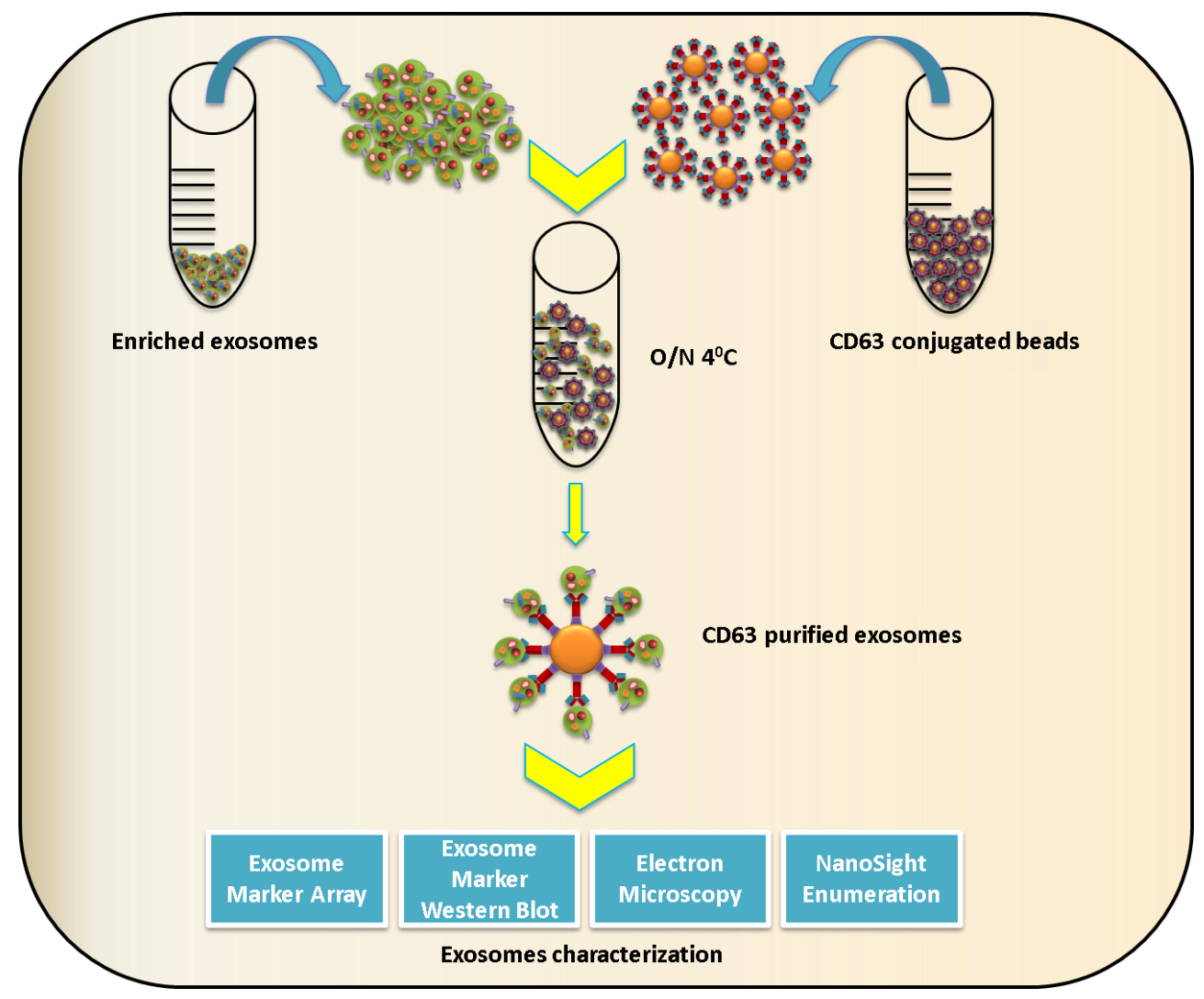

Figure 4. Schematic representation of exosome immune-isolation. To obtain exosomes free of contaminants, exosomes can be subjected to immunomagnetic selection using anti-CD63 antibody conjugated beads and then characterized by immunoblot, electron microscopy, and size determination.

\section{Transfer of Viral and Cellular Components by Exosomes and Their Role in Virus Replication and Transmission}

Although the field of exosomes and their contribution to replication and pathogenesis of RNA viruses remain largely unexplored, a few RNA viruses have been investigated, such as HIV-1, HTLV-1, HCV, and Dengue virus. Findings from these studies have demonstrated that exosomes released from virus-infected cells contain a variety of viral and host cellular factors that are able to modulate recipient host cell responses and lead to the establishment of productive infection.

\subsection{Exosomes as Carriers of Virus and Host RNA Species}

It has been reported that exosomes carry various cellular regulatory RNAs, including miRNAs, sncRNAs, and siRNAs [96]. Exosomes derived from virus-infected cells have been shown to carry viral components including viral mRNA, miRNA, and genomic RNA, as well as genetic regulatory elements. Among the RNA viruses, HIV-1 was the first one to be studied somewhat in detail in the context of modulation of exosome formation. Exosomes derived from HIV-1 infected cells or patients with HIV infection incorporate the viral transactivating response (TAR) element transcribed from the integrated provirus, which has been suggested to enhance HIV replication in the recipient cells via downregulation of apoptotis [42]. Unspliced HIV-1 RNA species are recruited to exosomes and the presence of a stretch 
of sequences within the 5' end of the Gag p17 open reading frame is sufficient for this recruitment, while single- or double-spliced HIV-1 RNA is not incorporated into exosomes. The incorporation of genomic HIV-1 RNA in exosomes is further increased if the producer cells express HIV-1 defective for viral genome packaging [97].

Exosome-like microvesicles isolated from serum during infection with human Pegivirus (an RNA virus within the Pegivirus genus of the Flaviviridae previously known as Hepatitis G virus) have been shown to carry viral RNA and to be able to transmit viral RNA to peripheral blood mononuclear cells in vitro, resulting in productive infection [98]. Exosomes released from HCV-infected cells contain HCV RNA, which can be successfully transferred to dendritic cells to establish productive infection [99]. Two subsequent studies confirmed that exosomes derived from HCV-infected hepatocytes contain the complete HCV genome and they have the ability to mediate transfer of replication-competent subgenomic HCV RNA to permissive naive cells, leading to viral RNA replication and productive infection [100,101]. Exosomes derived from HCV-infected patients have also been found to contain negative sense HCV RNA (replication competent viral RNA), in association with Ago2, HSP90, and miR-122 [102].

A recent study reported that exosomes derived from Human T-lymphotropic virus type 1 (HTLV-1)-infected cells contain the Tax, HBZ, and Env gene mRNA transcripts, suggesting that exosomes can serve as vehicles to deliver functional HTLV-1 mRNA to recipient cells [103].

Exosomes secreted from HIV-1-infected primary alveolar macrophages carry viral microRNAs vmiR88, vmiR99, and vmiR-TAR; these miRNAs have also been detected in exosomes purified from the sera of HIV-infected individuals. Viral microRNAs vmiR88 and vmiR99 were shown to stimulate signaling in macrophages, resulting in robust release of TNF $\alpha$ through macrophage endosomal TLR8 [104]. Expression of HIV Nef protein in macrophage-like cells results in selective recruitment of 47 miRNAs into exosomes, with two miRNAs selectively retained in the same cells [105], suggesting that modulation of exosomal RNA composition during a viral infection is a regulated process and that specific mechanisms exist to recruit or retain specific miRNAs/RNAs. Astrocytes exposed to a combination of HIV protein Tat and opiate drugs secreted exosomes with elevated levels of miR-29b. In human neurons exposed to miR-29b-enriched exosomes, platelet-derived growth factor-B expression was repressed and neuron viability was correspondingly decreased [106]. The presence of Ago2, an essential protein of RNA-induced silencing complex (RISC) for mediating miRNA-targeted gene suppression, and cellular miRNAs in exosomes secreted from HTLV-1-infected cells suggested that HTLV-1 could manipulate mRNA translation in recipient cells [107].

\subsection{Exosomes as Viral Protein Carriers}

Exosomal protein composition varies depending on cell type and disease state. Several RNA viruses have been shown to modulate not only host cell protein composition of exosomes but also to recruit their own proteins into exosomes. Exosomes from HIV-1-infected cells have been shown to incorporate both Gag [108] and Nef proteins [109,110]. The latter is incorporated into exosomes upon anchoring into lipid raft microdomains through its $\mathrm{N}$-terminal myristoylation and a stretch of basic amino acids residing in its alpha-helix-1 [111], as well as upon interaction with the host cell protein Mortalin [112]. 
Similar to HIV, the HTLV-1 transactivator protein Tax, a critical factor for proliferation and transformation of T cells, is incorporated in exosomes secreted from virally-infected cells [103]. Several cellular proteins also seem to be recruited to exosomes in a Tax-dependent manner, many of them involved in protein synthesis and antigen presentation [103]. Exosomes derived from HCV-infected cells have been shown to carry HCV core protein, in addition to apolipoproteins ApoE and ApoB [101]. In HCV-positive patients, the cellular membrane protein CD81 has been shown to associate with the envelope glycoprotein E2. Extracellular release of E2-CD81 within microvesicles is associated with increased virus fusing ability and infectivity of naive cells [113]. Table 1 enlists the protein and RNA species of RNA viruses recruited to exosomes.

Table 1. Viral protein and RNA species present in exosomes derived from RNA virus-infected cells.

\begin{tabular}{cc}
\hline & Protein and RNA Species of RNA Viruses Present in Exosomes \\
\hline Hiral Proteins & HCV: HCV core protein \\
& HTLV-1: Transactivator protein Tax \\
\hline \multirow{3}{*}{ Viral RNA and microRNA } & HIV: HIV-1 transactivating response (TAR) element RNA, microRNAs \\
& vmiR88, vmiR99 and vmiR-TAR, unspliced HIV-1 RNA species, \\
HCV: HCV genomic RNA & HTL : HTL-1 Tax, HBZ, and Env gene mRNA transcripts \\
\hline
\end{tabular}

\subsection{Role of Exosomes in Pathogenesis}

Immature dendritic cells capture HIV-1 and can transfer these captured HIV-1 particles to T cells. Wiley and Gummuluru, back in 2006, reported that exosomes derived from HIV-1 containing immature dendritic cells can transfer HIV-1 to $\mathrm{T}$ cells without de novo infection. Exosomes isolated with HLA-DR-1-conjugated magnetic beads from the supernatant of DCs exposed to HIV-luc reporter viruses incubated with Jurkat $\mathrm{T}$ cells resulted in productive infection of cells. They also reported that endocytosed virus particles were the main contributors to exocytosed virus fraction, as treatment of virus-exposed DCs with trypsin had no or a negligible effect on the amount of virus particles precipitated by HLA-DR-1-conjugated magnetic beads [114].

Although the role of exosomes in HIV infection has not yet been fully understood, increasing evidence suggests that exosomes facilitate both enhancement and inhibition of infection and replication, depending upon the cells of origin. For instance, exosomes derived from HIV-infected cells have been shown to contain the HIV coreceptors CCR5 and CXCR4, and transfer of these coreceptors to uninfected, non-permissive cells may enhance susceptibility to HIV infection [115,116]. In a recent study, Kadiu et al. reported that a portion of HIV virions shed from monocyte-derived macrophages is associated with exosomal aggregates and these entrapped virions demonstrate improved infectivity toward CD4 ${ }^{+}$ target cells, compared to purified HIV-1 virus particles [117]. HIV-infected and viremic individuals exhibit elevated levels of plasma cytokines. Many cytokines have been found to be markedly enriched in exosomes from HIV-positive individuals relative to negative controls and exposure of naive peripheral 
blood mononuclear cells to exosomes purified from HIV-positive patients induces CD38 expression on naive and central memory $\mathrm{CD}^{+}{ }^{+}$and $\mathrm{CD}^{+} \mathrm{T}$ cells, probably contributing to inflammation and viral propagation via bystander cell activation [118].

HIV accessory protein negative factor (Nef) is one of the earliest and most abundantly expressed viral proteins. Nef is also released in exosomes. Lenassi et al. (2010) reported that Nef not only stimulates its own export through exosomes, but these Nef exosomes also facilitate the depletion of $\mathrm{CD}^{+} \mathrm{T}$ cells that is a hallmark of acquired immunodeficiency syndrome (AIDS) [109]. In fact HIV Nef, through exosomes, induces the activation of resting $\mathrm{CD}^{+}{ }^{+} \mathrm{T}$ lymphocytes, rendering these quiescent $\mathrm{CD}^{+}{ }^{+} \mathrm{T}$ lymphocytes permissive to HIV-1 replication and thus stimulating viral spread [119]. HIV-1 Nef promotes viral replication and pathogenesis by mediating depletion of CD4 and MHC-I molecules. Nef binds to the cytosolic tail (CT) of CD4 and MHC-I and disrupts the intracellular trafficking of these proteins targeting them to multivesicular bodies (MVBs), and ultimately to lysosomes for degradation. In a recent study Carvalho et al. (2014) reported that exosomes secreted by CD4 ${ }^{+} \mathrm{T}$ cells, but not $\mathrm{CD}^{-}{ }^{-} \mathrm{T}$ cells, efficiently inhibit HIV-1 infection in vitro, suggesting that exosomal CD4 can bind to envelope proteins of HIV-1, hindering virus interaction with target cells and eventually reducing the infection [110]. They also showed that this effect could be reversed by depleting CD4 exosomes released by $\mathrm{CD}^{+} \mathrm{T}$ cells expressing Nef. The remaining exosomes have a reduced capacity to inhibit HV-1 infection in vitro [110]. HIV Nef also modulates exosomal miRNA composition, further suggesting a role for exosomes in HIV pathogenesis and viral replication [110].

Exosomes play an important role in HTLV-1 infection as well, probably by delivering functional HTLV-1 Tax protein, proinflammatory mediators, and viral mRNA transcripts of Tax, HBZ, and Env proteins. Along with other host proteins, major histocompatibility complex (MHC) class I A and class I E precursor were also identified in exosomes derived from HTLV-1 infected cells. The addition of C81 cell-derived exosomes (containing Tax protein) to myeloid dendritic cells resulted in a significant increase in the levels of IL-2, IL-5, and IL-6 cytokines. In fact, cell-free Tax could induce IL-10, IL-12, IL-17A, IFN- $\gamma$, and G-CSF secretion from dendritic cells. The findings of Jaworski et al. (2014) suggest that exosomes play a crucial role in signal transduction and may contribute to pathogenesis of HTLV-1 infection [103].

Human cytidine deaminase APOBEC3G (A3G) is part of a cellular defense system against HIV-1 as well as other retroviruses. In a recent study, Khatua et al. (2009) found that APOBEC3G secreted by cells in exosomes can confer resistance to both defective and wild-type HIV-1 infection in exosome recipient cells [120]. Esser et al. demonstrated that CD45, CD86, and MHC Class II molecules present in exosomes derived from HIV-infected cells may help in silencing immune response, therefore favoring virus replication [121]. Exosomes derived from HIV-1 infected CD8 ${ }^{+} \mathrm{T}$ cells suppressed replication of both CCR5- and CXCR4-tropic HIV-1 strains in vitro by inhibiting HIV-1 transcription in both acute and chronic models of infection [122]. Exosomes can not only transmit HCV to naive cells but also offer some degree of protection from HCV neutralizing antibodies. By making use of transmission electron microscopic imaging, Liu et al. demonstrated that HCV was present in both exosome-free and exosome-associated forms and the association with exosomes conferred the ability to resist anti-HCV antibody mediated neutralization, suggesting that HCV may utilize transmission via exosomes as an immune evasion mechanism [101,123]. 
Recently a new set of proteins called IFN inducible transmembrane proteins 1, 2, and 3 (IFITM1, 2, and 3) have been shown to display antiviral activities induced by IFN, conferring host cells resistance to various viral pathogens [124]. In their study Zhu et al. (2015) found that the IFITM3 protein level in host cells inversely correlates with their susceptibility to Dengue Virus-2 (DENV-2) infection [124]. Exosomes derived from HUVEC or HepG2 cells contain IFITM3 protein and can transfer this protein to neighboring cells. Investigating the functional aspect of this exosome-mediated transfer of IFITM3, they found that in recipient cells DENV-2 infection was effectively suppressed by the IFITM3-containing exosomes in a dose-dependent manner. The authors suggested that the IFITM3-containing exosomes did not affect the binding or post-entry steps during DENV-2 infection, but reduced the penetration of DENV-2 into cells, demonstrating an important role for exosomes in DENV-2 infection [124]. There is also evidence that some viruses harness exosomes to avoid immune recognition in the bloodstream or as reservoirs of virus latency. Hepatitis A virus (HAV), a non-enveloped virus, was found to be encapsulated into vesicles derived from endosomal membranes [47]. These enveloped HAV particles were fully infectious. They resembled exosomes and their biogenesis was dependent on ESCRTs and ESCRT effectors [47]. Their membrane cloak protected them from antibody neutralization and virus-specific antibodies appear only after 3-4 weeks of infection.

\section{Potential Applications in Viral Infections}

Exosomes appear to be an important tool of intercellular communication, as discussed above. However, their further use in various other processes is also being evaluated. The exosomes can be used as a diagnostic marker, as vaccines, and as a drug delivery vehicle for targeted or systemic delivery. Since exosomes have been detected in all bodily fluids, can be easily purified, and have a composition that varies in normal and diseased conditions, they can be exploited as diagnostic markers of diseases. However, the use of exosomes as a diagnostic marker for viral infection has not yet been explored adequately.

Targeted delivery is another area where the potential of exosomes to carry therapeutic cargo to specific organs or tissues is being evaluated. Expression of receptor-specific ligand molecules on the exosome surface through genetic engineering can transform exosomes into potent delivery vehicles that can deliver a drug/siRNA/miRNA based therapeutic moiety to cells or tissues of choice. In fact, the ability of exosomes to deliver therapeutic moiety or genetic material can be further improved by incorporating selected viral proteins into exosomes as virus-encoded envelope proteins exhibiting superior binding and entry specificity (reviewed in [125]). For instance, exosomes engineered to express a 29-mer peptide derived from the rabies virus glycoprotein (RVG), which specifically binds to acetylcholine receptors expressed on the brain cells, were exploited by Alvarez-Erviti et al. (2011) to transport small interfering RNAs to the brain [126]. The immature dendritic cells (DCs) were transfected with plasmids encoding exosomal protein Lamp2b, fused with the 29-mer RVG peptide. Exosomes were purified from DC cultures, loaded with GAPDH or BACE-1 siRNA, and injected intravenously through tail vein injection. The targeted delivery resulted in specific knockdown of GAPDH and BACE-1 in the mouse brain [127]. In other studies, DCs were transduced with adenoviral vector to express Interleukin (IL)-10, IL-4, or FasL, and the engineered exosomes were used to treat autoimmune disorders and inflammatory diseases (reviewed in [128]). Similar methods can be utilized to engineer exosomes to deliver siRNAs to control 
viral infections such as West Nile Virus or other viral infections of the brain or other organs like the liver or lungs. Exosomes are also being evaluated as vaccines in the field of infectious diseases. Aline et al. (2004), investigated the efficacy of DC2.4 cell line-derived exosomes to mount a protective immune response against toxoplasmosis [129]. They found that Toxoplasma gondii-pulsed DC-derived exosomes transferred to the spleen, elicited a strong systemic Th1-modulated Toxoplasma-specific immune response in vivo, and were able to protect the animals against Toxoplasma infection [129]. This suggests that exosomes can also be used for immunoprophylaxis against viral pathogens; however, systemic studies need to be conducted to evaluate the therapeutic or protective role engineered exosomes can play in the field of infectious diseases. Exosomes offer many advantages, including but not limited to being natural transport body vehicles of antigens and signals between cells, providing a stable environment for nucleic acids and proteins by protecting them from DNase, RNase, and proteinases, efficient association/interaction with antigen-presenting cells, and offering better molecular distribution capabilities as are present in all bodily fluids [125,130].

\section{Conclusions}

Various studies have demonstrated that exosomes are crucial intercellular communication channels and highlighted their potential role in viral transmission and modulation of immune responses, as viruses exploit the exosomal pathway for their assembly/budding, transfer of viral RNAs, and suppression of immune activation. In addition, exosomes could be utilized as diagnostic markers in viral infections and for targeted drug delivery. Since exosome research related to viral infections is still in an early stage, more studies are required to decipher the interplay between exosome biology and viruses, as a comprehensive understanding of exosome biology and its involvement in viral infections would permit the development of new strategies to interfere with viral replication and disease development.

\section{Acknowledgments}

This project was supported by NIH grant R01 AI062885 and P01 AI07924602. The authors would like to thank Cynthia Tribble for manuscript editing and submission.

\section{Author Contributions}

Harendra Singh Chahar, Xiaoyong Bao, and Antonella Casola planned and wrote the manuscript.

\section{Conflicts of Interest}

The authors declare no conflict of interest.

\section{References}

1. Johnstone, R.M.; Adam, M.; Hammond, J.R.; Orr, L.; Turbide, C. Vesicle formation during reticulocyte maturation. Association of plasma membrane activities with released vesicles (exosomes). J. Biol. Chem. 1987, 262, 9412-9420.

2. Harding, C.; Heuser, J.; Stahl, P. Receptor-mediated endocytosis of transferrin and recycling of the transferrin receptor in rat reticulocytes. J. Cell Biol. 1983, 97, 329-339. 
3. Harding, C.; Heuser, J.; Stahl, P. Endocytosis and intracellular processing of transferrin and colloidal gold-transferrin in rat reticulocytes: Demonstration of a pathway for receptor shedding. Eur. J. Cell Biol. 1984, 35, 256-263.

4. Zech, D.; Rana, S.; Buchler, M.W.; Zoller, M. Tumor-exosomes and leukocyte activation: An ambivalent crosstalk. Cell Commun. Signal. 2012, 10, e37.

5. Thery, C.; Regnault, A.; Garin, J.; Wolfers, J.; Zitvogel, L.; Ricciardi-Castagnoli, P.; Raposo, G.; Amigorena, S. Molecular characterization of dendritic cell-derived exosomes. Selective accumulation of the heat shock protein hsc73. J. Cell Biol. 1999, 147, 599-610. [CrossRef] [PubMed]

6. Lai, R.C.; Arslan, F.; Lee, M.M.; Sze, N.S.; Choo, A.; Chen, T.S.; Salto-Tellez, M.; Timmers, L.; Lee, C.N.; El Oakley, R.M.; et al. Exosome secreted by MSC reduces myocardial ischemia/reperfusion injury. Stem Cell Res. 2010, 4, 214-222.

7. Van, N.G.; Mallegol, J.; Bevilacqua, C.; Candalh, C.; Brugiere, S.; Tomaskovic-Crook, E.; Heath, J.K.; Cerf-Bensussan, N.; Heyman, M. Intestinal epithelial exosomes carry MHC class II/peptides able to inform the immune system in mice. Gut 2003, 52, 1690-1697.

8. Zhan, R.; Leng, X.; Liu, X.; Wang, X.; Gong, J.; Yan, L.; Wang, L.; Wang, Y.; Wang, X.; Qian, L.J. Heat shock protein 70 is secreted from endothelial cells by a non-classical pathway involving exosomes. Biochem. Biophys. Res. Commun. 2009, 387, 229-233.

9. Taylor, D.D.; Gercel-Taylor, C. MicroRNA signatures of tumor-derived exosomes as diagnostic biomarkers of ovarian cancer. Gynecol. Oncol. 2008, 110, 13-21.

10. Keryer-Bibens, C.; Pioche-Durieu, C.; Villemant, C.; Souquere, S.; Nishi, N.; Hirashima, M.; Middeldorp, J.; Busson, P. Exosomes released by EBV-infected nasopharyngeal carcinoma cells convey the viral latent membrane protein 1 and the immunomodulatory protein galectin 9 . BMC Cancer 2006, 6, e283. [CrossRef] [PubMed]

11. Wolfers, J.; Lozier, A.; Raposo, G.; Regnault, A.; Thery, C.; Masurier, C.; Flament, C.; Pouzieux, S.; Faure, F.; Tursz, T.; et al. Tumor-derived exosomes are a source of shared tumor rejection antigens for CTL cross-priming. Nat. Med. 2001, 7, 297-303.

12. Li, Q.L.; Bu, N.; Yu, Y.C.; Hua, W.; Xin, X.Y. Exvivo experiments of human ovarian cancer ascites-derived exosomes presented by dendritic cells derived from umbilical cord blood for immunotherapy treatment. Clin. Med. Oncol. 2008, 2, 461-467.

13. Almqvist, N.; Lonnqvist, A.; Hultkrantz, S.; Rask, C.; Telemo, E. Serum-derived exosomes from antigen-fed mice prevent allergic sensitization in a model of allergic asthma. Immunology 2008, $125,21-27$.

14. Gallo, A.; Tandon, M.; Alevizos, I.; Illei, G.G. The majority of microRNAs detectable in serum and saliva is concentrated in exosomes. PLoS ONE 2012, 7, e30679.

15. Navabi, H.; Croston, D.; Hobot, J.; Clayton, A.; Zitvogel, L.; Jasani, B.; Bailey-Wood, R.; Wilson, K.; Tabi, Z.; Mason, M.D.; et al. Preparation of human ovarian cancer ascites-derived exosomes for a clinical trial. Blood Cells Mol. Dis. 2005, 35, 149-152.

16. Admyre, C.; Johansson, S.M.; Qazi, K.R.; Filen, J.J.; Lahesmaa, R.; Norman, M.; Neve, E.P.; Scheynius, A.; Gabrielsson, S. Exosomes with immune modulatory features are present in human breast milk. J. Immunol. 2007, 179, 1969-1978. 
17. Saman, S.; Kim, W.; Raya, M.; Visnick, Y.; Miro, S.; Saman, S.; Jackson, B.; McKee, A.C.; Alvarez, V.E.; Lee, N.C.; et al. Exosome-associated tau is secreted in tauopathy models and is selectively phosphorylated in cerebrospinal fluid in early Alzheimer disease. J. Biol. Chem. 2012, 287, 3842-3849.

18. Street, J.M.; Barran, P.E.; Mackay, C.L.; Weidt, S.; Balmforth, C.; Walsh, T.S.; Chalmers, R.T.; Webb, D.J.; Dear, J.W. Identification and proteomic profiling of exosomes in human cerebrospinal fluid. J. Transl. Med. 2012, 10, e5.

19. Logozzi, M.; de, M.A.; Lugini, L.; Borghi, M.; Calabro, L.; Spada, M.; Perdicchio, M.; Marino, M.L.; Federici, C.; Iessi, E.; et al. High levels of exosomes expressing CD63 and caveolin-1 in plasma of melanoma patients. PLOS ONE 2009, 4, e5219.

20. Admyre, C.; Johansson, S.M.; Paulie, S.; Gabrielsson, S. Direct exosome stimulation of peripheral human T cells detected by ELISPOT. Eur. J. Immunol. 2006, 36, 1772-1781.

21. Ali, S.A.; Huang, M.B.; Campbell, P.E.; Roth, W.W.; Campbell, T.; Khan, M.; Newman, G.; Villinger, F.; Powell, M.D.; Bond, V.C. Genetic characterization of HIV type 1 Nef-induced vesicle secretion. AIDS Res. Hum. Retrovir. 2010, 26, 173-192.

22. Meckes, D.G., Jr.; Raab-Traub, N. Microvesicles and viral infection. J. Virol. 2011, 85, 12844-12854.

23. Masyuk, A.I.; Masyuk, T.V.; Larusso, N.F. Exosomes in the pathogenesis, diagnostics and therapeutics of liver diseases. J. Hepatol. 2013, 59, 621-625.

24. Vella, L.J.; Sharples, R.A.; Nisbet, R.M.; Cappai, R.; Hill, A.F. The role of exosomes in the processing of proteins associated with neurodegenerative diseases. Eur. Biophys. J. 2008, 37, 323-332.

25. Bard, M.P.; Hegmans, J.P.; Hemmes, A.; Luider, T.M.; Willemsen, R.; Severijnen, L.A.; van Meerbeeck, J.P.; Burgers, S.A.; Hoogsteden, H.C.; Lambrecht, B.N. Proteomic analysis of exosomes isolated from human malignant pleural effusions. Am. J. Respir. Cell Mol. Biol. 2004, 31, 114-121.

26. Schorey, J.S.; Bhatnagar, S. Exosome function: From tumor immunology to pathogen biology. Traffic 2008, 9, 871-881.

27. Meckes, D.G., Jr.; Gunawardena, H.P.; Dekroon, R.M.; Heaton, P.R.; Edwards, R.H.; Ozgur, S.; Griffith, J.D.; Damania, B.; Raab-Traub, N. Modulation of B-cell exosome proteins by gamma herpesvirus infection. Proc. Natl. Acad. Sci. USA 2013, 110, E2925-E2933.

28. Meckes, D.G., Jr.; Shair, K.H.; Marquitz, A.R.; Kung, C.P.; Edwards, R.H.; Raab-Traub, N. Human tumor virus utilizes exosomes for intercellular communication. Proc. Natl. Acad. Sci. USA 2010, 107, 20370-20375.

29. Pegtel, D.M.; Cosmopoulos, K.; Thorley-Lawson, D.A.; van Eijndhoven, M.A.; Hopmans, E.S.; Lindenberg, J.L.; de Gruijl, T.D.; Wurdinger, T.; Middeldorp, J.M. Functional delivery of viral miRNAs via exosomes. Proc. Natl. Acad. Sci. USA 2010, 107, 6328-6333.

30. Testa, J.S.; Apcher, G.S.; Comber, J.D.; Eisenlohr, L.C. Exosome-driven antigen transfer for MHC class II presentation facilitated by the receptor binding activity of influenza hemagglutinin. $J$. Immunol. 2010, 185, 6608-6616. 
31. Gourzones, C.; Gelin, A.; Bombik, I.; Klibi, J.; Verillaud, B.; Guigay, J.; Lang, P.; Temam, S.; Schneider, V.; Amiel, C.; et al. Extra-cellular release and blood diffusion of BART viral micro-RNAs produced by EBV-infected nasopharyngeal carcinoma cells. Virol. J. 2010, 7, e271.

32. Raposo, G.; Nijman, H.W.; Stoorvogel, W.; Liejendekker, R.; Harding, C.V.; Melief, C.J.; Geuze, H.J. B lymphocytes secrete antigen-presenting vesicles. J. Exp. Med. 1996, 183, 1161-1172.

33. Raposo, G.; Tenza, D.; Mecheri, S.; Peronet, R.; Bonnerot, C.; Desaymard, C. Accumulation of major histocompatibility complex class II molecules in mast cell secretory granules and their release upon degranulation. Mol. Biol. Cell 1997, 8, 2631-2645.

34. Zitvogel, L.; Regnault, A.; Lozier, A.; Wolfers, J.; Flament, C.; Tenza, D.; Ricciardi-Castagnoli, P.; Raposo, G.; Amigorena, S. Eradication of established murine tumors using a novel cell-free vaccine: Dendritic cell-derived exosomes. Nat. Med. 1998, 4, 594-600.

35. Thery, C.; Boussac, M.; Veron, P.; Ricciardi-Castagnoli, P.; Raposo, G.; Garin, J.; Amigorena, S. Proteomic analysis of dendritic cell-derived exosomes: A secreted subcellular compartment distinct from apoptotic vesicles. J. Immunol. 2001, 166, 7309-7318.

36. Blanchard, N.; Lankar, D.; Faure, F.; Regnault, A.; Dumont, C.; Raposo, G.; Hivroz, C. TCR activation of human $\mathrm{T}$ cells induces the production of exosomes bearing the TCR/CD3/zeta complex. J. Immunol. 2002, 168, 3235-3241.

37. Escola, J.M.; Kleijmeer, M.J.; Stoorvogel, W.; Griffith, J.M.; Yoshie, O.; Geuze, H.J. Selective enrichment of tetraspan proteins on the internal vesicles of multivesicular endosomes and on exosomes secreted by human B-lymphocytes. J. Biol. Chem. 1998, 273, 20121-20127.

38. Clayton, A.; Court, J.; Navabi, H.; Adams, M.; Mason, M.D.; Hobot, J.A.; Newman, G.R.; Jasani, B. Analysis of antigen presenting cell derived exosomes, based on immuno-magnetic isolation and flow cytometry. J. Immunol. Methods 2001, 247, 163-174.

39. Li, M.; Aliotta, J.M.; Asara, J.M.; Tucker, L.; Quesenberry, P.; Lally, M.; Ramratnam, B. Quantitative proteomic analysis of exosomes from HIV-1-infected lymphocytic cells. Proteomics 2012, 12, 2203-2211.

40. Verweij, F.J.; van Eijndhoven, M.A.; Middeldorp, J.; Pegtel, D.M. Analysis of viral microRNA exchange via exosomes in vitro and in vivo. Methods Mol. Biol. 2013, 1024, 53-68.

41. Batagov, A.O.; Kurochkin, I.V. Exosomes secreted by human cells transport largely mRNA fragments that are enriched in the 3'-untranslated regions. Biol. Direct 2013, 8, e12.

42. Narayanan, A.; Iordanskiy, S.; Das, R.; van, D.R.; Santos, S.; Jaworski, E.; Guendel, I.; Sampey, G.; Dalby, E.; Iglesias-Ussel, M.; et al. Exosomes derived from HIV-1-infected cells contain trans-activation response element RNA. J. Biol. Chem. 2013, 288, 20014-20033.

43. Bellingham, S.A.; Coleman, B.M.; Hill, A.F. Small RNA deep sequencing reveals a distinct miRNA signature released in exosomes from prion-infected neuronal cells. Nucleic Acids Res. 2012, 40, 10937-10949.

44. Jenjaroenpun, P.; Kremenska, Y.; Nair, V.M.; Kremenskoy, M.; Joseph, B.; Kurochkin, I.V. Characterization of RNA in exosomes secreted by human breast cancer cell lines using next-generation sequencing. PeerJ 2013, 1, e201. 
45. Cheng, L.; Sun, X.; Scicluna, B.J.; Coleman, B.M.; Hill, A.F. Characterization and deep sequencing analysis of exosomal and non-exosomal miRNA in human urine. Kidney Int. 2014, $86,433-444$.

46. Miranda, K.C.; Bond, D.T.; Levin, J.Z.; Adiconis, X.; Sivachenko, A.; Russ, C.; Brown, D.; Nusbaum, C.; Russo, L.M. Massively parallel sequencing of human urinary exosome/microvesicle RNA reveals a predominance of non-coding RNA. PLOS ONE 2014, 9, e96094.

47. White, I.J.; Bailey, L.M.; Aghakhani, M.R.; Moss, S.E.; Futter, C.E. EGF stimulates annexin 1-dependent inward vesiculation in a multivesicular endosome subpopulation. EMBO J. 2006, $25,1-12$.

48. Ostrowski, M.; Carmo, N.B.; Krumeich, S.; Fanget, I.; Raposo, G.; Savina, A.; Moita, C.F.; Schauer, K.; Hume, A.N.; Freitas, R.P.; et al. Rab27a and Rab27b control different steps of the exosome secretion pathway. Nat. Cell Biol. 2010, 12, 19-30.

49. Mathivanan, S.; Ji, H.; Simpson, R.J. Exosomes: Extracellular organelles important in intercellular communication. J. Proteomics 2010, 73, 1907-1920.

50. Pant, S.; Hilton, H.; Burczynski, M.E. The multifaceted exosome: Biogenesis, role in normal and aberrant cellular function, and frontiers for pharmacological and biomarker opportunities. Biochem. Pharmacol. 2012, 83, 1484-1494.

51. Simpson, R.J.; Jensen, S.S.; Lim, J.W. Proteomic profiling of exosomes: Current perspectives. Proteomics 2008, 8, 4083-4099.

52. Simpson, R.J.; Lim, J.W.; Moritz, R.L.; Mathivanan, S. Exosomes: Proteomic insights and diagnostic potential. Expert. Rev. Proteomics 2009, 6, 267-283.

53. Subra, C.; Laulagnier, K.; Perret, B.; Record, M. Exosome lipidomics unravels lipid sorting at the level of multivesicular bodies. Biochimie 2007, 89, 205-212.

54. Valadi, H.; Ekstrom, K.; Bossios, A.; Sjostrand, M.; Lee, J.J.; Lotvall, J.O. Exosome-mediated transfer of mRNAs and microRNAs is a novel mechanism of genetic exchange between cells. Nat. Cell Biol. 2007, 9, 654-659.

55. Lotvall, J.; Valadi, H. Cell to cell signalling via exosomes through esRNA. Cell Adhes. Migr. 2007, 1, 156-158.

56. Nolte-'t Hoen, E.N.; Buermans, H.P.; Waasdorp, M.; Stoorvogel, W.; Wauben, M.H.; 't Hoen, P.A. Deep sequencing of RNA from immune cell-derived vesicles uncovers the selective incorporation of small non-coding RNA biotypes with potential regulatory functions. Nucleic Acids Res. 2012 , 40, 9272-9285.

57. Mittelbrunn, M.; Gutierrez-Vazquez, C.; Villarroya-Beltri, C.; Gonzalez, S.; Sanchez-Cabo, F.; Gonzalez, M.A.; Bernad, A.; Sanchez-Madrid, F. Unidirectional transfer of microRNA-loaded exosomes from T cells to antigen-presenting cells. Nat. Commun. 2011, 2, 282.

58. Montecalvo, A.; Larregina, A.T.; Shufesky, W.J.; Stolz, D.B.; Sullivan, M.L.; Karlsson, J.M.; Baty, C.J.; Gibson, G.A.; Erdos, G.; Wang, Z.; et al. Mechanism of transfer of functional microRNAs between mouse dendritic cells via exosomes. Blood 2012, 119, 756-766. 
59. Li, C.C.; Eaton, S.A.; Young, P.E.; Lee, M.; Shuttleworth, R.; Humphreys, D.T.; Grau, G.E.; Combes, V.; Bebawy, M.; Gong, J.; et al. Glioma microvesicles carry selectively packaged coding and non-coding RNAs which alter gene expression in recipient cells. RNA Biol. 2013, 10, 1333-1344.

60. Keller, S.; Sanderson, M.P.; Stoeck, A.; Altevogt, P. Exosomes: From biogenesis and secretion to biological function. Immunol. Lett. 2006, 107, 102-108.

61. Van, N.G.; Porto-Carreiro, I.; Simoes, S.; Raposo, G. Exosomes: A common pathway for a specialized function. J. Biochem. 2006, 140, 13-21.

62. Woodman, P.G.; Futter, C.E. Multivesicular bodies: Co-ordinated progression to maturity. Curr. Opin. Cell Biol. 2008, 20, 408-414.

63. Perez-Hernandez, D.; Gutierrez-Vazquez, C.; Jorge, I.; Lopez-Martin, S.; Ursa, A.; Sanchez-Madrid, F.; Vazquez, J.; Yanez-Mo, M. The intracellular interactome of tetraspanin-enriched microdomains reveals their function as sorting machineries toward exosomes. J. Biol. Chem. 2013, 288, 11649-11661.

64. Record, M.; Subra, C.; Silvente-Poirot, S.; Poirot, M. Exosomes as intercellular signalosomes and pharmacological effectors. Biochem. Pharmacol. 2011, 81, 1171-1182.

65. Record, M.; Carayon, K.; Poirot, M.; Silvente-Poirot, S. Exosomes as new vesicular lipid transporters involved in cell-cell communication and various pathophysiologies. Biochim. Biophys. Acta 2014, 1841, 108-120.

66. Katzmann, D.J.; Babst, M.; Emr, S.D. Ubiquitin-dependent sorting into the multivesicular body pathway requires the function of a conserved endosomal protein sorting complex, ESCRT-I. Cell 2001, 106, 145-155.

67. Babst, M.; Katzmann, D.J.; Snyder, W.B.; Wendland, B.; Emr, S.D. Endosome-associated complex, ESCRT-II, recruits transport machinery for protein sorting at the multivesicular body. Dev. Cell 2002, 3, 283-289.

68. Wollert, T.; Wunder, C.; Lippincott-Schwartz, J.; Hurley, J.H. Membrane scission by the ESCRT-III complex. Nature 2009, 458, 172-177.

69. Tamai, K.; Tanaka, N.; Nakano, T.; Kakazu, E.; Kondo, Y.; Inoue, J.; Shiina, M.; Fukushima, K.; Hoshino, T.; Sano, K.; et al. Exosome secretion of dendritic cells is regulated by Hrs, an ESCRT-0 protein. Biochem. Biophys. Res. Commun. 2010, 399, 384-390.

70. Stuffers, S.; Sem, W.C.; Stenmark, H.; Brech, A. Multivesicular endosome biogenesis in the absence of ESCRTs. Traffic 2009, 10, 925-937.

71. Van, N.G.; Charrin, S.; Simoes, S.; Romao, M.; Rochin, L.; Saftig, P.; Marks, M.S.; Rubinstein, E.; Raposo, G. The tetraspanin CD63 regulates ESCRT-independent and -dependent endosomal sorting during melanogenesis. Dev. Cell 2011, 21, 708-721.

72. Hsu, C.; Morohashi, Y.; Yoshimura, S.; Manrique-Hoyos, N.; Jung, S.; Lauterbach, M.A.; Bakhti, M.; Gronborg, M.; Mobius, W.; Rhee, J.; et al. Regulation of exosome secretion by Rab35 and its GTPase-activating proteins TBC1D10A-C. J. Cell Biol. 2010, 189, 223-232.

73. Buschow, S.I.; Nolte-'t Hoen, E.N.; van, N.G.; Pols, M.S.; ten, B.T.; Lauwen, M.; Ossendorp, F.; Melief, C.J.; Raposo, G.; Wubbolts, R.; et al. MHC II in dendritic cells is targeted to lysosomes or T cell-induced exosomes via distinct multivesicular body pathways. Traffic 2009, 10, 1528-1542. 
74. Mobius, W.; van, D.E.; Ohno-Iwashita, Y.; Shimada, Y.; Heijnen, H.F.; Slot, J.W.; Geuze, H.J. Recycling compartments and the internal vesicles of multivesicular bodies harbor most of the cholesterol found in the endocytic pathway. Traffic 2003, 4, 222-231.

75. Chen, B.J.; Lamb, R.A. Mechanisms for enveloped virus budding: Can some viruses do without an ESCRT? Virology 2008, 372, 221-232.

76. Harrison, M.S.; Sakaguchi, T.; Schmitt, A.P. Paramyxovirus assembly and budding: Building particles that transmit infections. Int. J. Biochem. Cell Biol. 2010, 42, 1416-1429.

77. Mori, Y.; Koike, M.; Moriishi, E.; Kawabata, A.; Tang, H.; Oyaizu, H.; Uchiyama, Y.; Yamanishi, K. Human herpesvirus-6 induces MVB formation, and virus egress occurs by an exosomal release pathway. Traffic 2008, 9, 1728-1742. [CrossRef] [PubMed]

78. Thery, C.; Amigorena, S.; Raposo, G.; Clayton, A. Isolation and characterization of exosomes from cell culture supernatants and biological fluids. Curr. Protoc. Cell Biol. 2006. [CrossRef]

79. Cheruvanky, A.; Zhou, H.; Pisitkun, T.; Kopp, J.B.; Knepper, M.A.; Yuen, P.S.; Star, R.A. Rapid isolation of urinary exosomal biomarkers using a nanomembrane ultrafiltration concentrator. Am. J. Physiol. Ren. Physiol. 2007, 292, F1657-F1661. [CrossRef] [PubMed]

80. Chen, C.; Skog, J.; Hsu, C.H.; Lessard, R.T.; Balaj, L.; Wurdinger, T.; Carter, B.S.; Breakefield, X.O.; Toner, M.; Irimia, D. Microfluidic isolation and transcriptome analysis of serum microvesicles. Lab Chip 2010, 10, 505-511.

81. Ashcroft, B.A.; de, S.J.; Yuana, Y.; Osanto, S.; Bertina, R.; Kuil, M.E.; Oosterkamp, T.H. Determination of the size distribution of blood microparticles directly in plasma using atomic force microscopy and microfluidics. Biomed. Microdevices 2012, 14, 641-649.

82. Shao, H.; Min, C.; Issadore, D.; Liong, M.; Yoon, T.J.; Weissleder, R.; Lee, H. Magnetic Nanoparticles and microNMR for Diagnostic Applications. Theranostics 2012, 2, 55-65.

83. Koga, K.; Matsumoto, K.; Akiyoshi, T.; Kubo, M.; Yamanaka, N.; Tasaki, A.; Nakashima, H.; Nakamura, M.; Kuroki, S.; Tanaka, M.; et al. Purification, characterization and biological significance of tumor-derived exosomes. Anticancer Res. 2005, 25, 3703-3707.

84. Lakadamyali, M.; Rust, M.J.; Babcock, H.P.; Zhuang, X. Visualizing infection of individual influenza viruses. Proc. Natl. Acad. Sci. USA 2003, 100, 9280-9285.

85. Melikyan, G.B.; Barnard, R.J.; Abrahamyan, L.G.; Mothes, W.; Young, J.A. Imaging individual retroviral fusion events: From hemifusion to pore formation and growth. Proc. Natl. Acad. Sci. USA 2005, 102, 8728-8733.

86. Mischler, R.; Metcalfe, I.C. Inflexal V a trivalent virosome subunit influenza vaccine: Production. Vaccine 2002, 20 (Suppl. S5), B17-B23.

87. Ferreira, G.P.; Trindade, G.S.; Vilela, J.M.; da Silva, M.I.; Andrade, M.S.; Kroon, E.G. Climbing the steps of viral atomic force microscopy: Visualization of Dengue virus particles. J. Microsc. 2008, 231, 180-185.

88. Lindenbach, B.D.; Evans, M.J.; Syder, A.J.; Wolk, B.; Tellinghuisen, T.L.; Liu, C.C.; Maruyama, T.; Hynes, R.O.; Burton, D.R.; McKeating, J.A.; et al. Complete replication of hepatitis C virus in cell culture. Science 2005, 309, 623-626. 
89. Bess, J.W., Jr.; Gorelick, R.J.; Bosche, W.J.; Henderson, L.E.; Arthur, L.O. Microvesicles are a source of contaminating cellular proteins found in purified HIV-1 preparations. Virology 1997, 230, 134-144.

90. Gluschankof, P.; Mondor, I.; Gelderblom, H.R.; Sattentau, Q.J. Cell membrane vesicles are a major contaminant of gradient-enriched human immunodeficiency virus type-1 preparations. Virology 1997, 230, 125-133.

91. Hutchinson, E.C.; Charles, P.D.; Hester, S.S.; Thomas, B.; Trudgian, D.; Martinez-Alonso, M.; Fodor, E. Conserved and host-specific features of influenza virion architecture. Nat. Commun. 2014, 5, 4816.

92. Cantin, R.; Fortin, J.F.; Tremblay, M. The amount of host HLA-DR proteins acquired by HIV-1 is virus strain- and cell type-specific. Virology 1996, 218, 372-381.

93. Raposo, G.; Moore, M.; Innes, D.; Leijendekker, R.; Leigh-Brown, A.; Benaroch, P.; Geuze, H. Human macrophages accumulate HIV-1 particles in MHC II compartments. Traffic 2002, 3, 718-729.

94. Nguyen, D.G.; Booth, A.; Gould, S.J.; Hildreth, J.E. Evidence that HIV budding in primary macrophages occurs through the exosome release pathway. J. Biol. Chem. 2003, 278, 52347-52354.

95. Cantin, R.; Methot, S.; Tremblay, M.J. Plunder and stowaways: Incorporation of cellular proteins by enveloped viruses. J. Virol. 2005, 79, 6577-6587.

96. Vojtech, L.; Woo, S.; Hughes, S.; Levy, C.; Ballweber, L.; Sauteraud, R.P.; Strobl, J.; Westerberg, K.; Gottardo, R.; Tewari, M.; et al. Exosomes in human semen carry a distinctive repertoire of small non-coding RNAs with potential regulatory functions. Nucleic Acids Res. 2014, 42, 7290-7304.

97. Columba, C.S.; Federico, M. Sequences within RNA coding for HIV-1 Gag p17 are efficiently targeted to exosomes. Cell. Microbiol. 2013, 15, 412-429.

98. Chivero, E.T.; Bhattarai, N.; Rydze, R.T.; Winters, M.A.; Holodniy, M.; Stapleton, J.T. Human pegivirus RNA is found in multiple blood mononuclear cells in vivo and serum-derived viral RNA-containing particles are infectious in vitro. J. Gen. Virol. 2014, 95, 1307-1319.

99. Dreux, M.; Garaigorta, U.; Boyd, B.; Decembre, E.; Chung, J.; Whitten-Bauer, C.; Wieland, S.; Chisari, F.V. Short-range exosomal transfer of viral RNA from infected cells to plasmacytoid dendritic cells triggers innate immunity. Cell Host Microbe 2012, 12, 558-570.

100. Longatti, A.; Boyd, B.; Chisari, F.V. Virion-Independent Transfer of Replication-Competent Hepatitis C Virus RNA between Permissive Cells. J. Virol. 2015, 89, 2956-2961.

101. Ramakrishnaiah, V.; Thumann, C.; Fofana, I.; Habersetzer, F.; Pan, Q.; de Ruiter, P.E.; Willemsen, R.; Demmers, J.A.; Stalin, R.V.; Jenster, G.; et al. Exosome-mediated transmission of hepatitis C virus between human hepatoma Huh7.5 cells. Proc. Natl. Acad. Sci. USA 2013, 110, 13109-13113.

102. Bukong, T.N.; Momen-Heravi, F.; Kodys, K.; Bala, S.; Szabo, G. Exosomes from hepatitis C infected patients transmit HCV infection and contain replication competent viral RNA in complex with Ago2-miR122-HSP90. PLoS Pathog. 2014, 10, e1004424. [CrossRef] [PubMed] 
103. Jaworski, E.; Narayanan, A.; van, D.R.; Shabbeer-Meyering, S.; Iordanskiy, S.; Saifuddin, M.; Das, R.; Afonso, P.V.; Sampey, G.C.; Chung, M.; et al. Human T-lymphotropic virus type 1-infected cells secrete exosomes that contain Tax protein. J. Biol. Chem. 2014, 289, 22284-22305.

104. Bernard, M.A.; Zhao, H.; Yue, S.C.; Anandaiah, A.; Koziel, H.; Tachado, S.D. Novel HIV-1 miRNAs stimulate TNFalpha release in human macrophages via TLR8 signaling pathway. PLoS ONE 2014, 9, e106006.

105. Aqil, M.; Naqvi, A.R.; Mallik, S.; Bandyopadhyay, S.; Maulik, U.; Jameel, S. The HIV Nef protein modulates cellular and exosomal miRNA profiles in human monocytic cells. J. Extracell. Vesicles 2014, 3. [CrossRef]

106. Hu, G.; Yao, H.; Chaudhuri, A.D.; Duan, M.; Yelamanchili, S.V.; Wen, H.; Cheney, P.D.; Fox, H.S.; Buch, S. Exosome-mediated shuttling of microRNA-29 regulates HIV Tat and morphine-mediated neuronal dysfunction. Cell Death Dis. 2012, 3, e381.

107. Sampey, G.C.; Meyering, S.S.; Asad, Z.M.; Saifuddin, M.; Hakami, R.M.; Kashanchi, F. Exosomes and their role in CNS viral infections. J. Neurovirol. 2014, 20, 199-208.

108. Fang, Y.; Wu, N.; Gan, X.; Yan, W.; Morrell, J.C.; Gould, S.J. Higher-order oligomerization targets plasma membrane proteins and HIV gag to exosomes. PLoS Biol. 2007, 5, e158.

109. Lenassi, M.; Cagney, G.; Liao, M.; Vaupotic, T.; Bartholomeeusen, K.; Cheng, Y.; Krogan, N.J.; Plemenitas, A.; Peterlin, B.M. HIV Nef is secreted in exosomes and triggers apoptosis in bystander CD4+ T cells. Traffic 2010, 11, 110-122.

110. De Carvalho, J.V.; de Castro, R.O.; da Silva, E.Z.; Silveira, P.P.; da Silva-Januario, M.E.; Arruda, E.; Jamur, M.C.; Oliver, C.; Aguiar, R.S.; daSilva, L.L. Nef neutralizes the ability of exosomes from CD4+ T cells to act as decoys during HIV-1 infection. PLoS ONE 2014, 9, e113691.

111. Arenaccio, C.; Chiozzini, C.; Columba-Cabezas, S.; Manfredi, F.; Federico, M. Cell activation and HIV-1 replication in unstimulated CD4+ T lymphocytes ingesting exosomes from cells expressing defective HIV-1. Retrovirology 2014, 11, e46. [CrossRef] [PubMed]

112. Shelton, M.N.; Huang, M.B.; Ali, S.A.; Powell, M.D.; Bond, V.C. Secretion modification region-derived peptide disrupts HIV-1 Nef's interaction with mortalin and blocks virus and Nef exosome release. J. Virol. 2012, 86, 406-419.

113. Masciopinto, F.; Giovani, C.; Campagnoli, S.; Galli-Stampino, L.; Colombatto, P.; Brunetto, M.; Yen, T.S.; Houghton, M.; Pileri, P.; Abrignani, S. Association of hepatitis C virus envelope proteins with exosomes. Eur. J. Immunol. 2004, 34, 2834-2842.

114. Wiley, R.D.; Gummuluru, S. Immature dendritic cell-derived exosomes can mediate HIV-1 trans infection. Proc. Natl. Acad. Sci. USA 2006, 103, 738-743.

115. Mack, M.; Kleinschmidt, A.; Bruhl, H.; Klier, C.; Nelson, P.J.; Cihak, J.; Plachy, J.; Stangassinger, M.; Erfle, V.; Schlondorff, D. Transfer of the chemokine receptor CCR5 between cells by membrane-derived microparticles: A mechanism for cellular human immunodeficiency virus 1 infection. Nat. Med. 2000, 6, 769-775. 
116. Rozmyslowicz, T.; Majka, M.; Kijowski, J.; Murphy, S.L.; Conover, D.O.; Poncz, M.; Ratajczak, J.; Gaulton, G.N.; Ratajczak, M.Z. Platelet- and megakaryocyte-derived microparticles transfer CXCR4 receptor to CXCR4-null cells and make them susceptible to infection by X4-HIV. AIDS 2003, 17, 33-42.

117. Kadiu, I.; Narayanasamy, P.; Dash, P.K.; Zhang, W.; Gendelman, H.E. Biochemical and biologic characterization of exosomes and microvesicles as facilitators of HIV-1 infection in macrophage. J. Immunol. 2012, 189, 744-754. [CrossRef] [PubMed]

118. Konadu, K.A.; Chu, J.; Huang, M.B.; Amancha, P.K.; Armstrong, W.; Powell, M.D.; Villinger, F.; Bond, V.C. Association of Cytokines With Exosomes in the Plasma of HIV-1-Seropositive Individuals. J. Infect. Dis. 2014. [CrossRef]

119. Arenaccio, C.; Chiozzini, C.; Columba-Cabezas, S.; Manfredi, F.; Affabris, E.; Baur, A.; Federico, M. Exosomes from human immunodeficiency virus type 1 (HIV-1)-infected cells license quiescent CD4+ T lymphocytes to replicate HIV-1 through a Nef- and ADAM17-dependent mechanism. J. Virol. 2014, 88, 11529-11539.

120. Khatua, A.K.; Taylor, H.E.; Hildreth, J.E.; Popik, W. Exosomes packaging APOBEC3G confer human immunodeficiency virus resistance to recipient cells. J. Virol. 2009, 83, 512-521.

121. Esser, M.T.; Graham, D.R.; Coren, L.V.; Trubey, C.M.; Bess, J.W., Jr.; Arthur, L.O.; Ott, D.E.; Lifson, J.D. Differential incorporation of CD45, CD80 (B7-1), CD86 (B7-2), and major histocompatibility complex class I and II molecules into human immunodeficiency virus type 1 virions and microvesicles: Implications for viral pathogenesis and immune regulation. J. Virol. 2001, 75, 6173-6182.

122. Tumne, A.; Prasad, V.S.; Chen, Y.; Stolz, D.B.; Saha, K.; Ratner, D.M.; Ding, M.; Watkins, S.C.; Gupta, P. Noncytotoxic suppression of human immunodeficiency virus type 1 transcription by exosomes secreted from CD8+ T cells. J. Virol. 2009, 83, 4354-4364.

123. Liu, Z.; Zhang, X.; Yu, Q.; He, J.J. Exosome-associated hepatitis $\mathrm{C}$ virus in cell cultures and patient plasma. Biochem. Biophys. Res. Commun. 2014, 455, 218-222.

124. Zhu, X.; He, Z.; Yuan, J.; Wen, W.; Huang, X.; Hu, Y.; Lin, C.; Pan, J.; Li, R.; Deng, H.; et al. IFITM3-containing exosome as a novel mediator for anti-viral response in dengue virus infection. Cell. Microbiol. 2015, 17, 105-118.

125. Koppers-Lalic, D.; Hogenboom, M.M.; Middeldorp, J.M.; Pegtel, D.M. Virus-modified exosomes for targeted RNA delivery; a new approach in nanomedicine. Adv. Drug Deliv. Rev. 2013, 65, $348-356$.

126. Lentz, T.L. Rabies virus binding to an acetylcholine receptor alpha-subunit peptide. J. Mol. Recognit. 1990, 3, 82-88.

127. Alvarez-Erviti, L.; Seow, Y.; Yin, H.; Betts, C.; Lakhal, S.; Wood, M.J. Delivery of siRNA to the mouse brain by systemic injection of targeted exosomes. Nat. Biotechnol. 2011, 29, 341-345.

128. Viaud, S.; Thery, C.; Ploix, S.; Tursz, T.; Lapierre, V.; Lantz, O.; Zitvogel, L.; Chaput, N. Dendritic cell-derived exosomes for cancer immunotherapy: What's next? Cancer Res. 2010, 70, 1281-1285. 
129. Aline, F.; Bout, D.; Amigorena, S.; Roingeard, P.; Dimier-Poisson, I. Toxoplasma gondii antigen-pulsed-dendritic cell-derived exosomes induce a protective immune response against $\mathrm{T}$. gondii infection. Infect. Immun. 2004, 72, 4127-4137.

130. Van den Boorn, J.G.; Schlee, M.; Coch, C.; Hartmann, G. SiRNA delivery with exosome nanoparticles. Nat. Biotechnol. 2011, 29, 325-326.

(C) 2015 by the authors; licensee MDPI, Basel, Switzerland. This article is an open access article distributed under the terms and conditions of the Creative Commons Attribution license (http://creativecommons.org/licenses/by/4.0/). 